\section{Extension of range of the Marine Puffer Fish Chelonodon patoca (Tetraodontiformes: Tetraodontidae) to freshwater habitat of Kerala, India}

\section{Arunachalam ${ }^{1}$, M. Muralidharan² \& P. Sivakumar ${ }^{2}$ \\ 1,2 Sri Paramakalyani Centre For Environmental Sciences, Manonmaniam Sundaranar University, Alwarkurichi, Tamil Nadu 627412, India \\ Email: ${ }^{1}$ arunacm @gmail.com}

Tetraodon travancoria and Chelonodon patoca, both belonging to the family Tetraodontidae, are the two puffer fish species reported in the freshwater habitats of the Western Ghats, India Hora \& Nair (1941) described Tetraodon travancoria from the Pamba River, Kerala. Later Easa \& Shaji (1997) recorded the same species from the Nilgiri Biosphere Reserve in Kerala, Western Ghats, and Remadevi et al. (2000) reported it in Mavincar in South Canara, Karnataka. Tetraodon travancoria was the only known freshwater puffer fish from Western Ghats until Chelonodon patoca was reported (Arunachalam et al. 1999) from the Aghnashini River in Kritikada, Karnataka. The present study reports the occurrence of Chelonodon patoca collected from the Payaswani River at Eranchipuzha in the Chandragiri River basin documenting the extension of the distribution of this species into Kerala.

\section{Materials and Methods}

Fish were collected using cast nets. Meristic counts and morphometric characters were measured and proportions were calculated following Hubbs \& Lagler (1958). The measurements that have been modified slightly are provided here in detail. Head length was measured from tip of snout to insertion point of pectoral fin. Eye diameter is the distance between anterior and posterior rim of eye through pupil. Inter orbital space is the distance between bony margins of eyes in

Date of publication 26 April 2009

ISSN $0974-7907$ (online) | 0974-7893 (print)

Editor: K. Rema Devi

\section{Manuscript details:}

Ms \# 01828

Received 26 July 2007

Final revised received 15 August 2008

Finally accepted 19 February 2009

Citation: Arunachalam, M., M. Muralidharan \& P. Sivakumar (2009). Extension of range of the Marine Puffer Fish Chelonodon patoca (Tetraodontiformes: Tetraodontidae) to freshwater habitat of Kerala, India. Journal of Threatened Taxa 1(4): 238-239.

Copyright: (C) M. Arunachalam, M. Muralidharan \& P. Sivakumar 2009. Creative Commons Attribution 3.0 Unported License. JoTT allows unrestricted use of this article in any medium for non-profit purposes, reproduction and distribution by providing adequate credit to the authors and the source of publication.

Acknowledgements: MA is grateful for financial assistance from National Agricultural Technology Project under the mission mode programme of "Germplasm Inventory and Gene Banking of Freshwater Fishes". We thank the Mission Leader and Director Dr. D. Kapoor and Dr. S.P. Singh, Principal Investigator of the Project. We also thank S.S. Mariappan for line drawings. dorsal position. Caudal fin length was measured from posterior end of urocentrum to tip of fin. Standard length was measured from snout tip to base of caudal fin. All measurements were made to the nearest $0.1 \mathrm{~m}$ using digital calipers. The specimens are housed in the registered collection of the Manonmaniam Sundaranar University Museum of Natural History (MSUMNH), Alwarkurichi. Tamil Nadu.

\section{Material examined}

30.i.2004, 5 ex., 37.76-59.23mm SL, Payaswani River, Chandragiri River basin at Eranchipuzha, Kasaragod District, Kerala, coll. M. Arunachalam, M. Muralidharan \& P. Sivakumar, MSUMNH 46.

\section{Comparative Materials}

1999, 1 ex, 51.47mm SL, Aghnashini River at Kritikada Village, Karnataka, coll. M. Arunachalam \& J.A. Johnson, MSUMNH 21.

\section{Chelonodon patoca (Hamilton-Buchanan)}

Tetraodon patoca Hamilton-Buchanan 1822, by original designation; estuaries of the Ganges, (West Bengal, India) 7, 362, Pl. 18, fig.2

\section{Diagnosis}

Body heavy and fairly elongate, gill opening not reaching below middle of pectoral fin base. Nasal organ in the form of a depression with slightly raised margin expanded before and behind into a pair of elongate flaps. Two lateral lines. Pectoral fin round and caudal fin truncate, with curved edges. Back and side of body with round fluorescent olive green to yellowish spots, variable in number and size.

\section{Description}

Body arched dorsally; ventrally flat unless air sac bulged. Broad back, posterior part of body compressed, skin covered with simple retractile prickles, spines four rooted (Fig. 1a), Head broad its length 40.73-43.77 (42.15)\% SL (Table 1). Mouth terminal, jaws with median suture. Eyes large, in dorsolateral position situated slightly anterior to half the distance of head length. Eye diameter 22.72-30.36 (25.35)\% HL and inter orbital space 56.30-64.71 (61.43)\% HL. Nostril immediately near eye, nasal organ cuplike produced into two rounded flaps, gill opening narrow, ending before middle of pectoral fin base, predorsal distance 74.83-77.56 (76.22)\% SL covered by laminae, vent positioned very close to anal fin. Two lateral lines, upper one joins lower one behind anal fin, and reaches caudal fin base. Inconspicuous line around eyes, the circles thus formed are connected by an inter link at the nape

Dorsal fin round, inserted slightly behind the vent above anal fin. Its height less than length of head excluding snout $21.50-23.74(22.28) \%$ SL. Anal fin round 15.22-20.34 $(17.58) \% \mathrm{SL}$, its origin from first branched ray of dorsal fin above. Caudal fin truncate 34.53-37.05 (35.21)\% SL. Pectoral fins small and round, placed at middle of body, vertically in regard to height, its length roughly equal to snout length and $15.58-18.49(16.86) \% \mathrm{SL}$ 
Table 1. Morphometric and meristic characters of Chelonodon patoca from Karnataka and Kerala

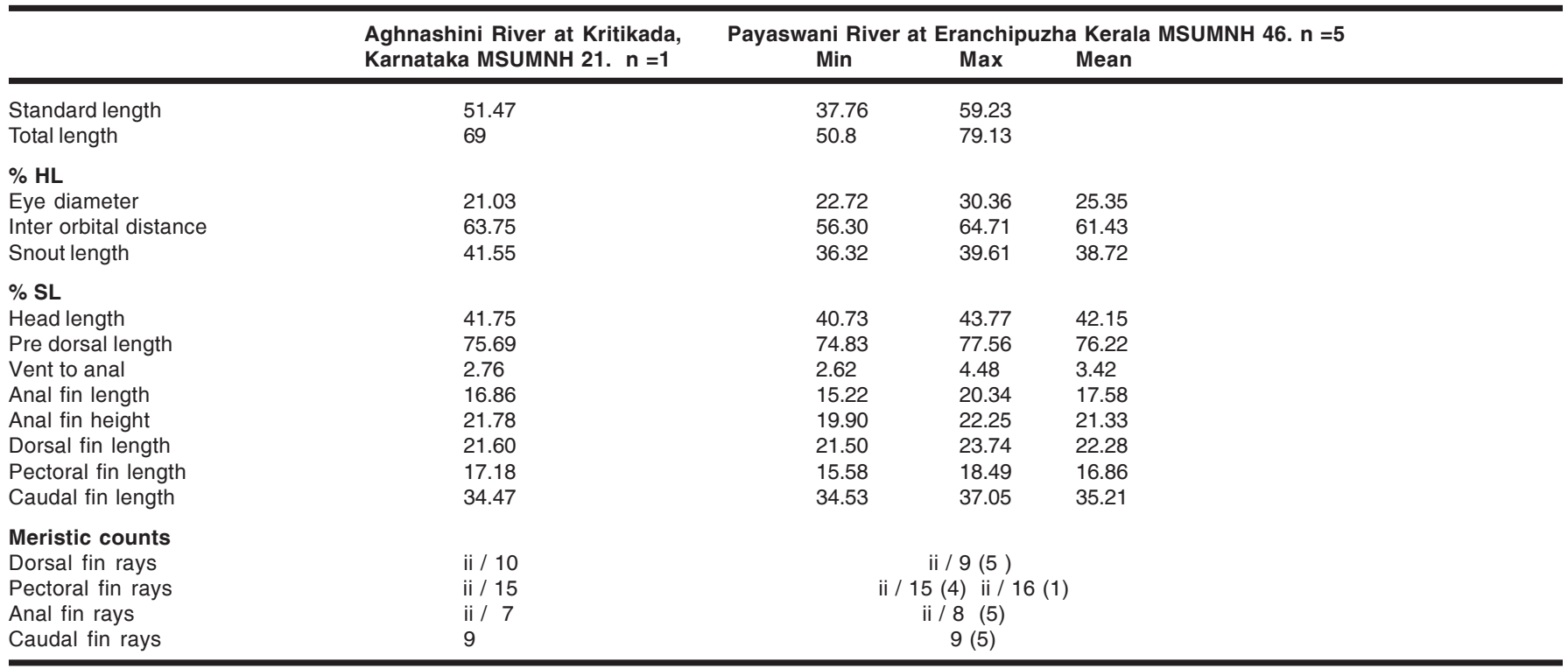

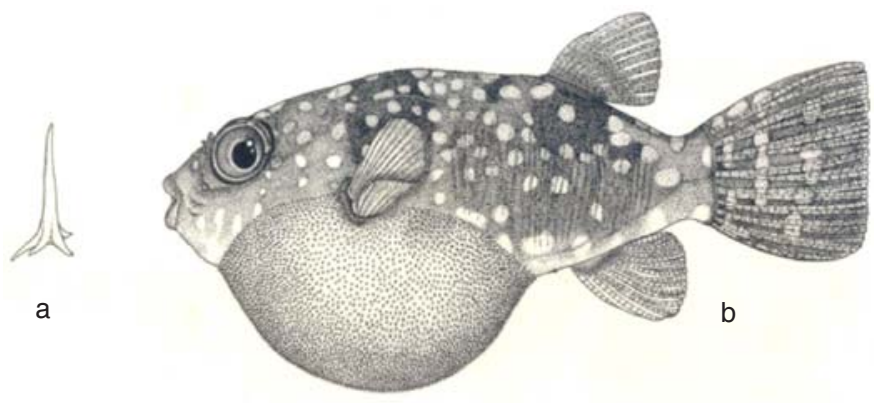

Figure 1. Lateral view of Chelonodon patoca and shape of fourrooted spine

a - Four-rooted spine; b - Lateral view of Chelonodon patoca

\section{Colour}

Upper surface of body deep grey, becoming white below. Abdomen silvery white. Back and sides with numerous small round olive fluorescent green spots extending up to caudal fin. Spots on caudal fin in vertical rows, the interspaces form two to three distinct dark bands, the posteriormost the broadest (Fig. 1b). Spots variable in size and form. Three black cross bands descend from back to middle of lateral surface of body, one passes over the head with a ' $V$ ' shaped light interorbital band posterior to it. Also is seen another band that extends backward in the median line towards an irregular band formed by congregation of spots of same colour. The second band, in the form of a saddle, is seen in the space between the pectoral fins on either side, the posterior one spreads from slightly ahead of the dorsal origin. Olive green spots encircle a part of the third band.

Colour in formalin: Fluorescent yellow colour turned to dirty white in preservation. Body pale grey on the dorsal surface, and the spots along the body are dull white but are prominent.

\section{Discussion}

Most of the meristic and morphometric characters studied for the five specimens are similar to the comparative material from the Aghnashini River in Karnataka except for the variation in number of branched rays and the shape of the distal margin of both the dorsal and anal fins. The branched rays of the dorsal fins in the specimen from Aghnashini were 10 versus 9 , the anal fins were 8 versus 7 and the shape of the margin of the dorsal and anal fins of the Aghnashini specimen tend to be more truncate versus round in the Payaswani specimens.

Chelonodon patoca (Hamilton-Buchanan 1822) was described from the estuary of the Ganges, West Bengal and is very common along the Coromandal Coast of India (Day 1875-78). It has also been reported from tropical Indo-West Pacific waters (Talwar \& Jhingran 1991). Its distribution in freshwater habitats of the Western Ghats was established when it was reported in the Aghnashini River in Karnataka. Now the specimens collected from the Payaswani River in Kerala represents a new record from the Kerala area of the Western Ghats.

\section{References}

Arunachalam, M., J.A. Johnson \& P.N. Shanthi (1999). A new record of the Marine Puffer fish Genus, Chelonodon (Tetraodontiformes, Tetraodontidae) from freshwater habitat of Western Ghats, India. Acta Zoologica Taiwanica 10: 11-14.

Day, F. (1875-78). The Fishes of India: Being a Natural History of the Fishes known to Inhabit the Seas and Fresh Waters of India, Burma and Ceylon. Text and atlas in 2 parts. London, Indian Reprint by Jagmander Book Agency, New Delhi, $x x+778,195 p l s$.

Easa, P.S. \& C.P. Shaji (1997). Freshwater fish diversity in Kerala part of the Nilgiri Biosphere Reserve. Current Science 73(2): 180-182.

Hamilton-Buchanan, F. (1822). An account of fishes found in the river Ganges and its branches. Edinburgh and London, viii+405, 39pls.

Hora, S.L. \& K.K. Nair (1941). Notes on fishes in the Indian museum. XLI. New Records of freshwater fishes from Travancore. Records of Indian Museum 43: 387-393.

Hubbs, C.L. \& K.F. Lagler (1958). Fishes of Great Lakes Region. University Michigan Press, Ann Arbor, 213pp.

Remadevi, K., T.J. Indra \& M.B. Raghunathan (2000). On a report of Tetraodon (Monotretus) travancoricus from South Canara, Karnataka, India. Journal of the Bombay Natural History Society 97(3) 441-442.

Talwar, P.K. \& A.G. Jhingran (1991). Inland Fishes of India and Adjacent Countries. Oxford and India Book House, New Delhi, 1158pp. 